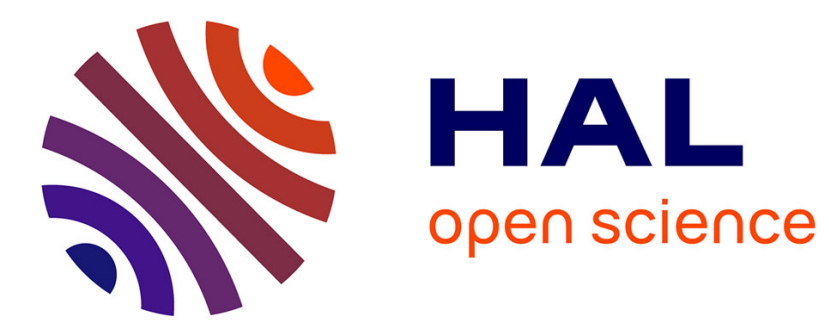

\title{
SYNCHRONIZATION OF OESTRUS AND OVULATION IN THE MARE WITH A TWO PG-HCG SEQUENCES TREATMENT
}

E. Palmer, Béatrice Jousset

\section{- To cite this version:}

E. Palmer, Béatrice Jousset. SYNCHRONIZATION OF OESTRUS AND OVULATION IN THE MARE WITH A TWO PG-HCG SEQUENCES TREATMENT. Annales de biologie animale, biochimie, biophysique, 1975, 15 (2), pp.471-480. hal-00896975

\section{HAL Id: hal-00896975 https://hal.science/hal-00896975}

Submitted on 1 Jan 1975

HAL is a multi-disciplinary open access archive for the deposit and dissemination of scientific research documents, whether they are published or not. The documents may come from teaching and research institutions in France or abroad, or from public or private research centers.
L'archive ouverte pluridisciplinaire HAL, est destinée au dépôt et à la diffusion de documents scientifiques de niveau recherche, publiés ou non, émanant des établissements d'enseignement et de recherche français ou étrangers, des laboratoires publics ou privés. 
Ann. Biol. anim. Bioch. Biophys., I975, 15 (2), 47x-48o.

\title{
SYNCHRONIZATION OF OESTRUS AND OVULATION IN THE MARE WITH A TWO PG-HCG SEQUENCES TREATMENT
}

\author{
E. PALMER and Béatrice JOUSSET \\ Station de Physiologie de la Reproduction, \\ Centre de Recherches de Tours, I. N.R.A., \\ B.P. 1, Nouzilly, 3\%380 Monnaie (France)
}

\section{SUMMARY}

The use of PG and HCG was investigated to obtain oestrus synchronization in the mare. According to preliminary results, a treatment of two PG-HCG sequences begun at any stage of the oestrus cycle ( $\mathrm{PG}$ on Day $\mathrm{T}_{\mathbf{0}}$ of treatment, $\mathrm{HCG}$ on Day $\mathrm{T}_{6}, \mathrm{PG}$ on Day $\mathrm{T}_{14}, \mathrm{HCG}$ on $\mathrm{Day}_{20}$ ) was tested in two groups of mares : 33 light mares treated in May and 15 Breton mares treated in september. This treatment induced synchronized ovulation in $75 \mathrm{p}$. roo treated mares in a 4 days interval. The mecanism of action is described; the comparison of induced ovulation with spontaneous ovulation in non-treated mares showed no differences. This treatment is efficient from April to September, period during which mares do not present ovarian inactivity. If fertility is good, this treatment should allow to inseminate the mares on Day $T_{19}$ and $T_{\mathbf{2 1}}$ of the treatment without oestrus detection.

The choice of the right time for mating or insemination of the mare is a great problem. Oestrus, the more classical criterion, is difficult to detect and does not allow a precise prediction of the time of ovulation. Two possibilities can be envisaged to make this choice easier : to improve this prediction or to induce oestrus and ovulation at predetermined times by a treatment. This second solution has the advantage of convenience and economy of labour. For this purpose we have used an analogue of $\mathrm{PGF}_{2}$ (Equimate ICI-8IOo8) and $\mathrm{HCG}$, two compounds which are known to be efficient in the mare.

The induction of luteolysis by prostaglandins (PG) or their analogues has been studied by several authors (Douglas and GINTHER, 1972; AlLEN and Rowson, I973; NODEN, OXENDER and HAFs, I974). When administered in a sufficient dose, the onset of oestrus occurs 48 to 72 hours later provided that the treatment is done during the luteal phase of the cycle at least four days after ovulation. But during 
the induced oestrus, AII,EN and Rowson (I973) have shown that ovulation is not perfectly synchronized.

In cycling mares, intramuscular or intraveinous injection of $\mathrm{HCG}$ on the second day of oestrus induces ovulation 24 to 48 hours later (LoY and Hughes, I966; Sullivan, PARker and LARSON, I973).

We therefore used a PG-HCG sequence ( $\mathrm{HCG} 6$ days after $\mathrm{PG}$ ) to reduce the variability of the follicular phase which follows the $\mathrm{PG}$ and allow the synchronization of ovulation that cannot be obtained with $\mathrm{PG}$ alone. But this treatment (one $\mathrm{PG}$ HCG sequence) would be efficient in only a proportion of a group of mares (those treated after day 4 of the luteal phase of the cycle). Then we have used two successive PG-HCG sequences to synchronize all animals. The resulting treatment is described in table $I$.

TABLE I

Synchronization treatment in the mave

$\begin{array}{llrl}\mathrm{T}_{0}= & \text { Day of first injection, independant of the stage of the oestrous cycle } \\ \mathrm{T}_{0} & \text { I quimate* } & 250 \mu \mathrm{g} & \text { IM injection } \\ \mathrm{T}_{6} & \text { HCG } & 2500 \mathrm{IU} & \text { IM injection } \\ \mathrm{T}_{14} & \text { Iquimate } & 250 \mu \mathrm{g} & \text { IM injection } \\ \mathrm{T}_{20} & \mathrm{HCG} & 2500 \mathrm{IU} & \text { IM injection }\end{array}$

* A prostaglandin analogue ICI-81008

\section{MA'TERIALS AND ME'THODS}

Our treatment has been tested in the two following experiments.

\section{Experiment $I$}

Thirty three mares of different breeds (Thoroughbred, French saddle Horse, French Trotter) have been treated in spring, the first PG injection being done one April 3o. The mares were observed for 13 days before treatment (Days $T_{-13}$ to $T_{-1}$ ), during the treatment $\left(T_{0}\right.$ to $T_{20}$ ) and for I I days post-treatment ( $T_{21}$ to $\left.T_{31}\right)$. stallion.

- Oestrous detection was done daily by teasing the mares in a "breeding stall " with a

- Rectal examination of the ovaries was done at least every other day, but it was done every day if the mare was in oestrus or if a growing follicle was found.

- Daily blood samples were taken from the jugular vein. Plasma progesterone level was measured by a radioimmunological technique (PALMER and JousSET, 1974).

\section{Experiment II}

The same treatment (table $I$ ) was used at the beginning of autumn $\left(T_{0}=\right.$ Sept. I 9 and 20) with 15 Breton mares (a draft horse breed) $2 \mathrm{I} / 2$ years old. This trial was done to test the use of our technique with natural mating on Day I9 and 2I of the treatment, without oestrous detection.

In this case, the observations were simplified : only the progesterone assay was done, every other day from $D T_{-18}$ to Day $T_{14}$, every day from day $T_{14}$ to Day $T_{29}$, every other day from Day $T_{28}$ do Day $T_{47}$.

Four Breton stallions of normal fertility were used to cover the mares on the chosen days, each stallion doing 2 services per day during four successive days. 


\section{RESUITS}

The ovarian activity of the mares during our synchronization treatment is shown in table 2 (Experiment I) and in table 3 (Experiment II). As the results are very similar, they were pooled for analysis.

TABLE 2

Individual ovarian activity of the 33 mares during experiment I

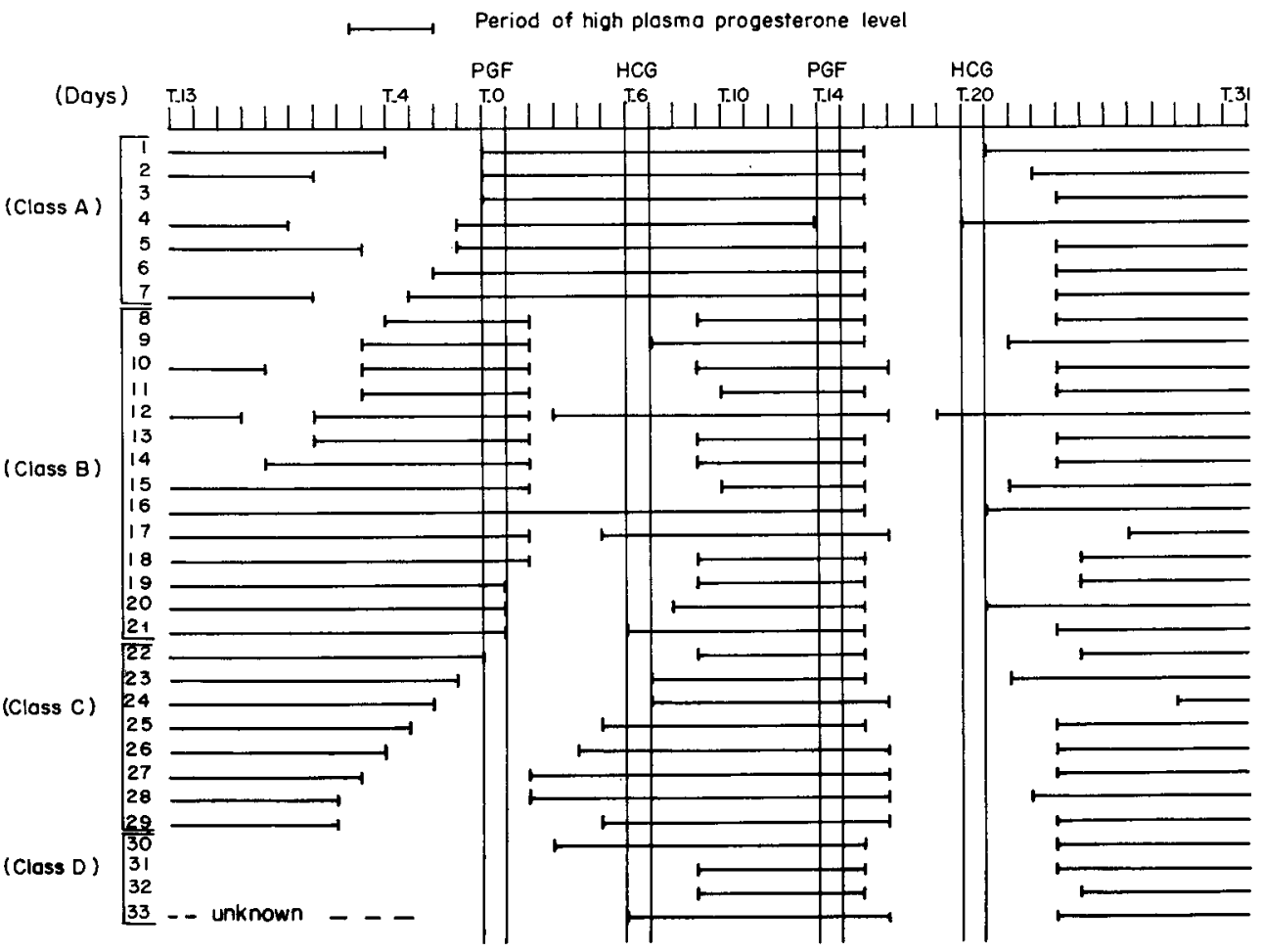

\section{I. - Effect of the treatment in cyclic mares}

Among the 48 treated mares, 4I responded in the expected way. Three types of response must be considered according to the period of the cycle on day $\mathrm{T}_{\mathbf{0}}$.

I. Beginning of the treatment on one of the first four days of the luteal phase (Class A).

The first PG injection is not efficient (fig. I). The luteal phase goes on. The first HCG has no visible effect. By contrast the second $P G$ injection $\left(T_{14}\right)$ done near the end of the luteal phase is efficient. A rapid luteolysis is induced. A follicular phase begins around day $T_{16}$ and ends around day $T_{22}$ after an ovulation induced by the 


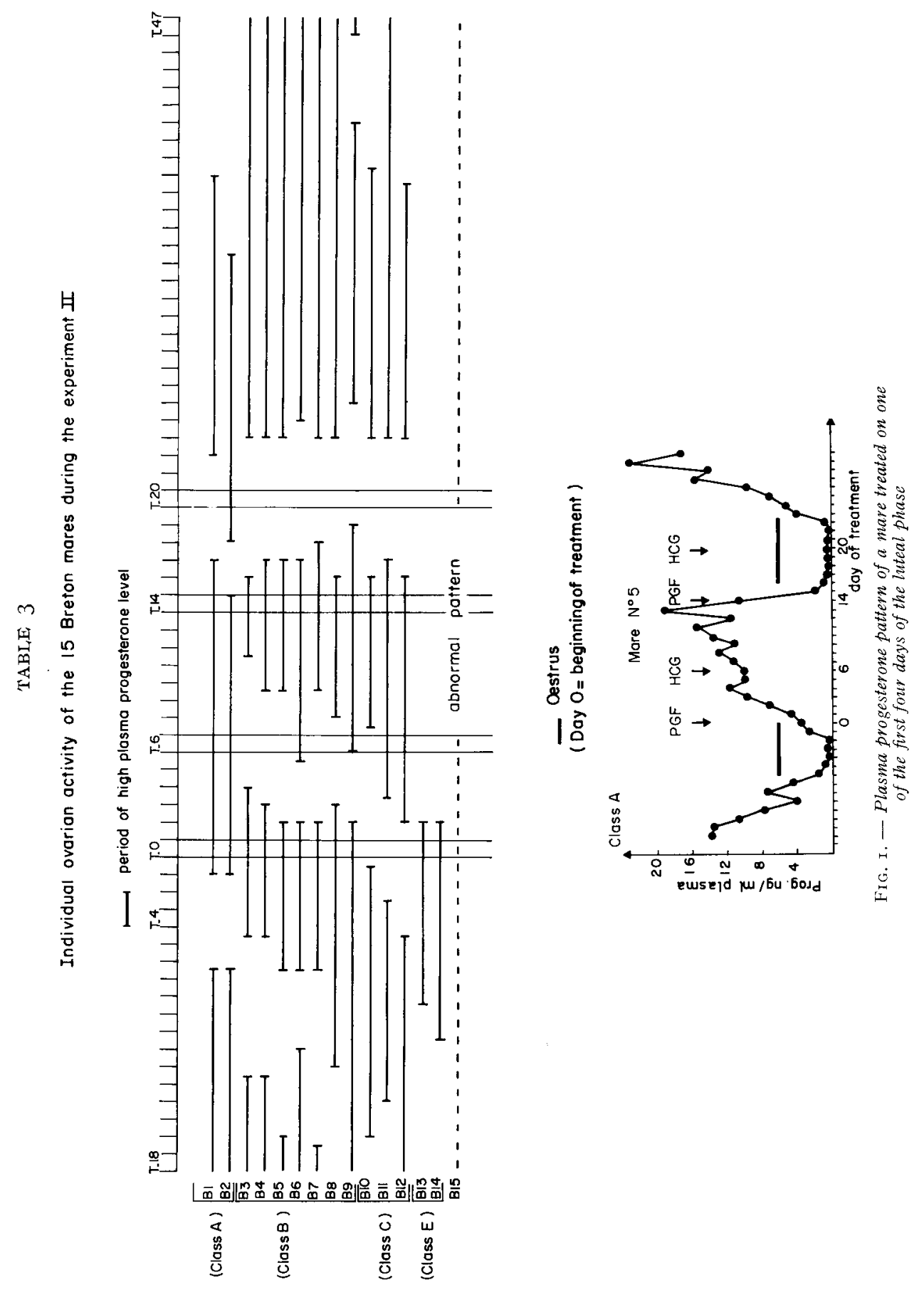


day $\Gamma_{20} \mathrm{HCG}$ injection. Ten mares ( 7 in Experiment $\mathrm{I}$ and 3 in Experiment II) have followed this pattern.

2. Beginning of treatment later in the luteal phase (Class B).

The first PG injection is then efficient (fig. 2). A follicular phase begins around day $\mathrm{T}_{2}$ and $\mathrm{HCG}$ induces an ovulation on day $\mathrm{T}_{8}$. The second $\mathrm{PG}$ injection is given on day six of a new luteal phase, late enough to induce luteolysis aroung day $T_{16}$. The induced follicular phase begins at the same time as in Class A ; likewise the HCG induced ovulation occurs around day $\mathrm{T}_{22}$. Mares in persistent luteal activity respond in the same way. This type of response was obtained in 2 I mares $(\mathrm{I} 4+7)$.

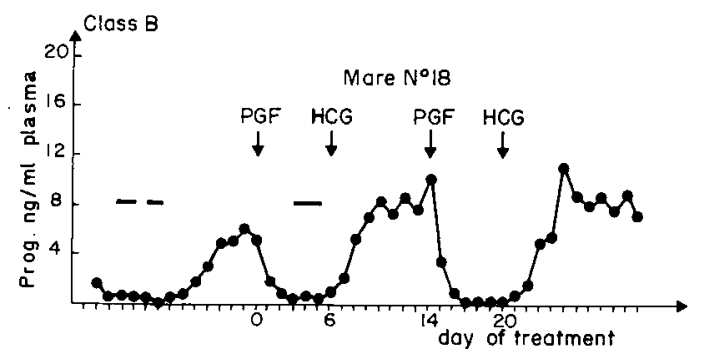

Fic. 2. - Plasma progesterone pattern of a mare treated during luteal phase, more than four days after ovulation

3. Beginning of treatment during the follicular phase of cycle (Class C).

The first PG injection does not disturb the cyclic pattern (fig. 3). The mare ovulates spontaneously before HCG injection, and is ready to respond to the second PG injection. Induced follicular phase and ovulation are synchronized with previous classes. Ten mares $(8+2)$ were in this case.

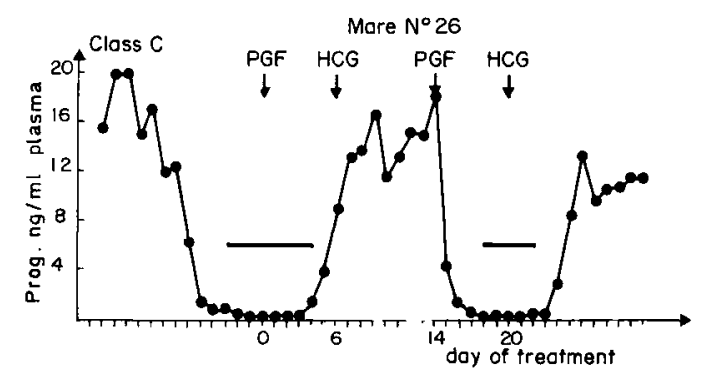

lig. 3. - Plasma progesterone pattern in a mare treated during follicular phase

\section{II. - Effect of treatment in non cyclic mares}

Seven mares did not follow the expected pattern. These animals were not cyclic, either at the beginning or at the end of the treatment.

- Four mares (Class I)) showed a low progesterone level ( < I ng/ml plasma) during the whole pretreatment period (fig. 4). These mares which did not show pattern of cyclic mares before treatment, however ovulated between day $\mathrm{T}_{\mathbf{0}}$ and day $\mathrm{T}_{8}$, 
either before or after the first HCG injection. They responded normally to the remainder of the treatment, and their induced follicular phase had a normal duration. This pattern was found only during the first experiment which took place at the end of the winter period of ovarian inactivity.

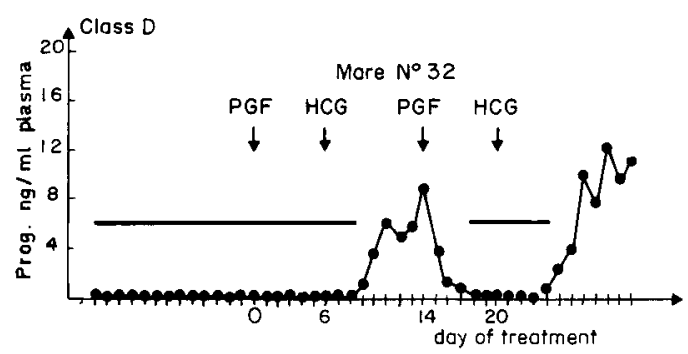

FIG. 4. - Plasma progesterone pattern of a mare treated in a prolonged low progesterone phase

- Two mares (Class E) treated during luteal phase did not ovulate after the luteolysis induced by the first PG injection. None of the two $\mathrm{HCG}$ injections induced ovulation and the progesterone level remained low from day $\mathrm{T}_{2}$ up to the end of the experiment (day $T_{47}$ ) (fig. 5). These two cases were found during the second experiment done at the end of September, the beginning of the winter period of ovarian inactivity.

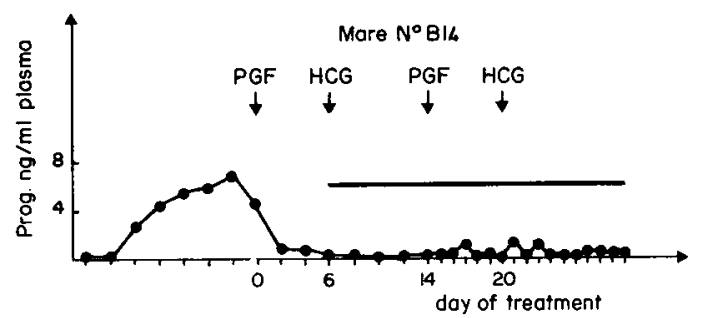

FIG. 5. - Plasma progesterone pattern of a mare showing an anovulatory period after the first $P G$ injection

- Finally, one mare in Experiment II had a non cyclic abnormal ovarian activity. Its progesterone level fluctuated around I $\mathrm{ng} / \mathrm{ml}$ plasma. In this case, the treatment did not induce a cycle.

\section{III. - Synchronization of ovulation}

Time of ovulation can be estimated by the progesterone pattern (PALMER and Jousset, I974). Indeed the plasma progesterone level exceeds I ng/ml 24 to 48 hours after ovulation. The distribution of progesterone rises is shown in figure 6 . A maximum (50 p. Ioo of the cases) occurs on day $\mathrm{T}_{24}$ consequent to ovulations occuring on day $\mathrm{T}_{22}$ or $\mathrm{T}_{23} .75 \mathrm{p}$. Ioo of the mares ovulated in a 4 days period during which two systematic inseminations could be done. The other observations done during the first experiment (table 4) confirmed this good synchronization of oestrus (73 p. Ioo beginning in a 4 days interval) and ovulation ( $85 \mathrm{p}$. Ioo detected in a 4 days interval). 


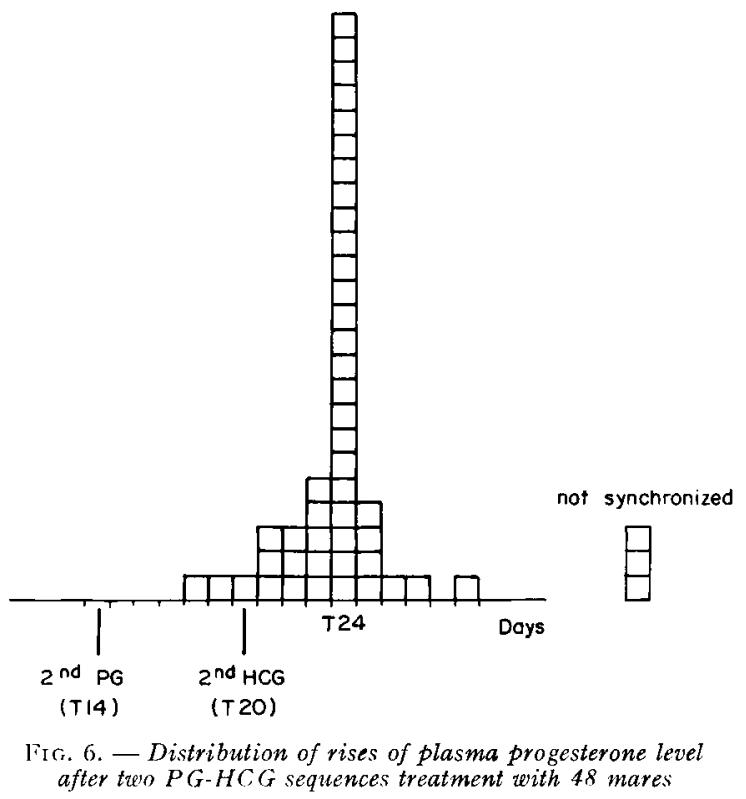

TABLE, 4

Synchronization of ovarian activity

(Experiment I)

I. Oestrus

Mares with synchronized oestrus $(\%) \ldots \ldots \ldots \ldots \ldots \ldots \ldots \ldots \ldots \ldots$

p. 100 of these oestrus beginning in a 4 days interval $\ldots \ldots \ldots \ldots \ldots \ldots . \ldots 3$

p. 100 of these oestrus ending in a $t_{t}$ days interval ............. 62

II. Progesterone pattern

p. 100 of mares with luteolysis in a 2 days interval . . . . . . . . . . . 97

p. 100 of mares with progesterone rise in a 4 days interval $\ldots \ldots \ldots \ldots .78$

III. Rectal palpation

p. 100 of detected ovulation $\ldots \ldots \ldots \ldots \ldots \ldots \ldots \ldots \ldots \ldots \ldots \ldots, \quad 60$

p. 100 of these ovulation in a 4 days interval .............. 85

\section{DISCUSSION}

Up to the present time, no technique has been proposed to synchronize ovulations in order to cover or inseminate mares without any oestrous detection. Therefore, no comparisons are possible. However our results are encouraging as they resulted in $75 \mathrm{p}$. Ioo of mares ovulating in a 96 hours period with two different breeds and in two different seasons. 
The presence of mares in ovarian inactivity at the beginning of Experiment I and at the end of Experiment II shows that we have worked at the limits of the favourable period. These limits are the same as those of the occurence of ovarian inactivity in non treated mares (PALMER and JoUSSET, I974). The existence of some periods of persistent luteal activity during summer is not an objection to the efficiency of our treatment as it includes a 1uteolytic effect. By contrast, any technique for the winter period should include stimulation of follicular activity.

Any change in the intervals between injections would probably have a negative effect on the synchronization rate : on the one hand induction of ovulation by HCG needs sufficient follicular growth and induction of 1uteolysis by PG a four-days-old corpus luteum ; therefore the intervals between injections must not be shortened. On the other hand, day $T_{14}$ is the moment of spontaneous luteolysis of mares of Class $\mathrm{A}$ and day $T_{21}$ the time of spontaneous ovulation of these mares. With longer intervals these mares would not be synchronized.

The observations made during the first experiment (table 4) give us some indication of the quality of the induced ovulation. Oestrus was present in $78 \mathrm{p}$. I00 of the mares, but it was sometimes difficult to detect. Only $60 \mathrm{p}$. Ioo induced ovulations were found by rectal palpation. This percentage is lower than normal as we usually detect 80 p. Ioo of ovulations. We think that it is the consequence of ovulation of smaller follicles. In spite of this small size, the formed corpus luteum has a normal progesterone secretion (fig. 7). In addition the quality of ovulation can be

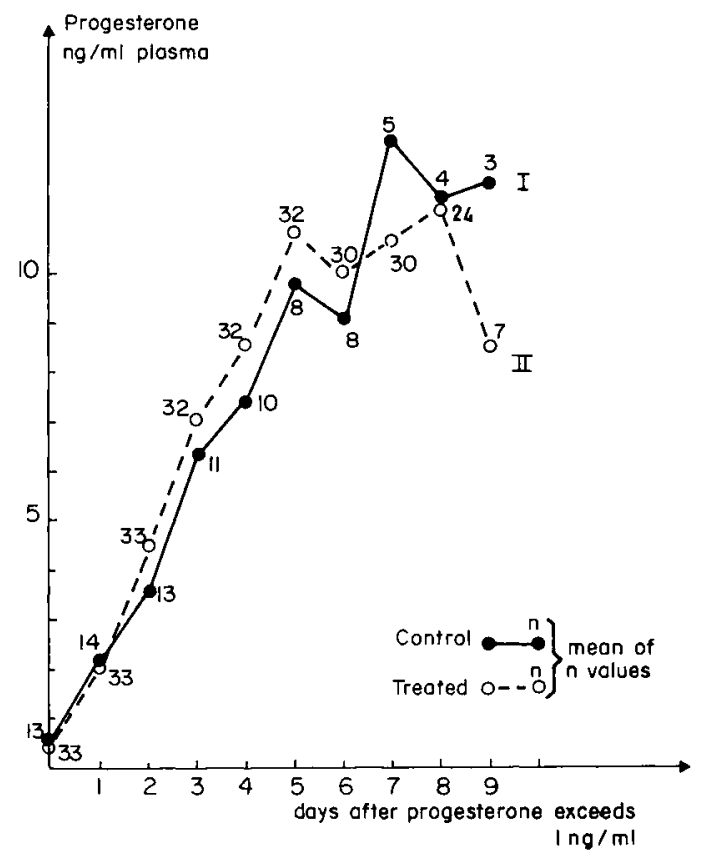

all differences are not significant

lis. 7. - Comparison between progesteronc increase after

I : natural ovulations

II : induced ovulations 
tested by fertility. At the present time, it is too early to give a definitive fertility rate. Among the I5 mares covered in October (Experiment II) 3 had no induced ovulation and one ovulated spontaneously before the first mating. Seven of the eleven remaining mares had still a high plasma progesterone level up to day $\mathrm{T}_{47}$ (25 days after ovulation); so they are probably pregnant (PALMER, THIMONIER, I EMON, I974). This result is encouraging enough to go on testing fertility in a larger number of animals.

\title{
CONCLUSION
}

The synchronization of oestrus and ovulation should eliminate many problems in horse breeding : choice of the right time for mating, better distribution of the work of the stallion, better management, possibility of use of artificial insemination.

Our technique (PG on day $\mathrm{T}_{0}, \mathrm{HCG}$ on day $\mathrm{T}_{6}, \mathrm{PG}$ on day $\mathrm{T}_{\mathbf{1}}, \mathrm{HCG}$ on day $\mathrm{T}_{\mathbf{2}}$ ) is a first solution for non lactating mares during the summer season. Other treatments must be found for post partum mares and for the winter period.

\section{Colloque : Control of sexual cycles in domestic animals} October 27-30, 1974, Nouzilly.

\author{
RÉSUMÉ \\ SYNCHRONISATION DE L'CESTRUS ET DE L'OVULATION CHEZ LA JUMENT \\ AVEC UN TRAITEMENT DE DEUX SÉQUENCES PG-HCG
}

L'utilisation de PG et HCG a été testée pour synchroniser les chaleurs chez la Jument. D'après des résultats préliminaires, un traitement de deux séquences $\mathrm{PG}-\mathrm{HCG}$, commencé à n'importe quel moment du cycle ( $P G$ au jour $T_{0}$ du traitement, $H C G$ au jour $T_{6}$, PG au jour $T_{14}, H_{C G}$ au jour $\mathrm{T}_{20}$ ) a été testé sur deux lots de juments : 33 juments de sang traitées en mai et $\mathrm{I} 5$ juments Bretonnes traitées en septembre. Ce traitement a induit la synchronisation des ovulations chez 75 p. Ioo des juments traitées, dans un intervalle de 4 jours. Le mécanisme d'action est décrit ; la comparaison des ovulations induites avec les ovulations spontanées chez des juments non traitées ne montre aucune différence. Ce traitement est efficace d'avril à septembre, période pendant laquelle la Jument ne présente pas d'inactivité ovarienne. Si la fertilité est bonne, ce traitement devrait permettre d'inséminer les juments les jours $T_{19}$ et $T_{21}$ du traitement sans détection d'oestrus.

\section{REFERENCES}

ALLEN W. R., Rowson L. E. A., 1973. Control of the mare's oestrous cycle by prostaglandins. $J$. Reprod. Fert., 33, 539.

Douglas R. H., Ginther O. J., I972. Effect of prostaglandin $\mathrm{F}_{2} \alpha$ on length of dioestrus in mares. Prostaglandins, 2, 265.

Loy R. G., Hughes J. P., I966. The effect of HCG on ovulation, length of estrus and fertility in the mare. Cornell Vet., $\mathbf{5 6}, 4 \mathrm{I}$.

Noden P. A., Oxender W. D., Hafs H. D., I974. Estrus, ovulation, progesterone and luteinizing hormone after prostaglandins $\mathrm{F}_{2} \propto$ in mares. Proc. Soc. exp. Biol. Med., 145, I45.

PaLmer E., Jousset B., I974. Urinary estrogen and plasma progesterone levels in cyclic and non cyclic mares. 1rst, intern. Symp. upon Equine Reproduction, Cambrids?. 
Patmer E, Thmonime J, Lemon M, 1974. Early pregnancy diagnosis in the mare by estimation of the level of progesterone in the peripheral blood. Liverst Prod Sa, 1, 197.

SultivaN J, J, PARKRR W G, LARsoN $\mathrm{L}$ L, r973. Duration of estrus and ovulation time in non lactating mares given human ohorionic gonadotropin during three successive oestrous periods. $J$. $A m$. Iet $A s s, 162,895$. 